\title{
Pengaruh Model Pembelajaran Langsung Berbantuan Media Laboratorium Terhadap Kreatifitas Fisika Siswa SMA
}

\author{
Ria Rizki Ekasari ${ }^{1}$, Gunawan ${ }^{1}$, Hairunnisyah Sahidu ${ }^{1}$ \\ ${ }^{1}$ Program Studi Pendidikan Fisika \\ FKIP Universitas Mataram \\ Mataram, Indonesia \\ Email: rizuki_reia@rocketmail.com
}

\begin{abstract}
This research aims to investigate the influence of direct instruction model with virtual laboratory media toward student creativity in physics using "pretest-posttest control group design". The creativity data collected by essay type test shows that pre-test average grade of experimental class is 41 and control class is 36, while post-test average grade of experimental class is 74 and control class is 69. Based on data analysis, creativity of male student in physics is higher than female student. The average grade of male student is 72 while female student is 70 . The result of hypothesis testing using polled variance $t$-test with significance level of $5 \%$ is $t_{\text {calculation }}=2,518>t_{\text {table }}=1,99601$ or, in other words, the calculated $t$ value is greater than the value given in the table. It can be concluded that direct instruction model with virtual laboratory media influences high school student creativity in physics.
\end{abstract}

Keywords: direct instruction, virtual laboratory, creativity.

\section{Pendahuluan}

Perbaikan demi perbaikan telah dilakukan dalam dunia pendidikan untuk mendapatkan kualitas hasil belajar yang lebih baik. Beberapa perubahan yang dilakukan pemerintah diantaranya yaitu dengan mengganti kurikulum KTSP menjadi K13, walaupun sekarang sudah kembali lagi ke KTSP dan hanya beberapa sekolah yang terpilih saja yang menerapkan K13. Perkembangan teknologi dan informasi saat ini sangatlah pesat. Perkembangan itu juga diiringi dengan semakin cepatnya perkembangan ilmu pengetahuan dan teknologi, terutama pada bidang teknologi komputer. Sudah banyak produk dan manfaat yang diperoleh dari perkembangan tersebut, salah satunya dalam dunia pendidikan. Dalam dunia pendidikan teknologi komputer sering kali digunakan sebagai salah satu media untuk pembelajaran misalnya Microsoft power point, adobe flash, komik digital, serta masih banyak jenis lainnya yang digunakan secara online maupun offline.

Adanya beberapa perubahan dalam dunia pendidikan tersebut memberikan dampak yang besar dalam proses pembelajaran misalnya kesiapan dan kemampuan guru untuk mengajar serta kemampuan guru mendisain pembelajaran agar selalu menarik untuk diperhatikan oleh peserta didik. Dampak tersebut mengharuskan guru untuk selalu mengupdate informasi tentang bagaimana seharusnya mengajar serta media yang digunakan. Sehingga diharapkan peningkatan kualitas pendidikan menjadi lebih baik [1].

Peningkatan kualitas pendidikan tidak dapat terlepaskan dari peran pembelajarannya. Penerapan pendekatan sistem pembelajaran berbasis kompetensi mengarah kepada pengelolaan pembelajaran secara individu dan menempatkan peserta didik sebagai subyek yang harus merencanakan, menggali, menginterprestasi serta mengevaluasi hasil belajarnya sendiri. Sedangkan pengajar sebagai fasilitator yang harus senantiasa siap melayani kebutuhan belajar peserta didik. Pengajar dituntut mampu menciptakan situasi pembelajaran yang menyenangkan (enjoyable learning), mampu mendorong motivasi dan minat belajar.

Salah satu pembelajaran menyenangkan yang menjadi trend belakangan ini adalah pembelajaran berbantuan virtual laboratory atau sering disebut virtual lab. Virtual laboratory merupakan suatu bentuk objek multimedia interaktif. Objek multimedia interaktif terdiri dari berbagai format heterogen termasuk teks, hiperteks, suara, gambar, animasi, video, dan grafik. Menurut Gunawan [2], secara umum virtual laboratory, seperti simulasi, dimaksudkan untuk mentransfer pengetahuan baik konseptual maupun prosedural.

Namun demikian untuk mencapai tujuan tersebut, lembaga pendidikan dihadapkan pada berbagai permasalahan menyangkut diri peserta didik, pengajar maupun fasilitas lainnya. Permasalahanpermasalahan tersebut juga timbul pada pembelajaran mata pelajaran Fisika. Dari pengamatan pada proses pembelajaran tampak bahwa motivasi peserta didik dalam mengikuti pelajaran perlu mendapat perhatian. Hal ini terlihat dari kurangnya antusiasme, kurangnya kesadaran dan kemauan kuat untuk bertanya, serta kurang mampu mengutarakan ide yang merupakan bentuk kreativitas sebagai upaya memahami materi masih rendah. Hal tersebut disebabkan oleh rendahnya penguasaan konsep peserta didik sehingga 
mereka tidak kreatif dalam mengerjakan soal-soal yang diberikan oleh guru.

Selain itu pembelajaran yang membosankan dan fasilitas yang kurang memadai di sekolah menjadi penghambat dalam mengembangkan kreativitas siswa maupun gurunya. Oleh karena itu, salah satu model pembelajaran yang tepat untuk menangani permasalah di atas adalah model pembelajaran langsung (Direct Instruction). Model pembelajaran langsung merupakan cara yang paling efektif untuk mengajarkan konsep dan keterampilanketerampilan yang eksplisit kepada siswa yang berprestasi rendah sekalipun [3]. Menurut Setyosari [4] model pembelajaran langsung adalah salah satu pendekatan mengajar yang dirancang khusus untuk menunjang proses belajar siswa yang berkaitan dengan pengetahuan deklaratif dan pengetahuan prosedural yang terstruktur dengan baik yang dapat diajarkan dengan pola kegiatan yang bertahap selangkah demi selangkah. Dari hasil penelitian sebelumnya yang telah dilakukan oleh Arnika [5], model direct instruction terbukti efektif diterapkan dalam proses belajar mengajar dengan persentase aktivitas siswa yang dikehendaki selama proses pembelajaran sebesar 90,09\%. Secara klasikal siswa tuntas dengan persentase $91,18 \%$, respon siswa terhadap pembelajaran ini adalah positif yaitu sebesar 75\% dari 34 siswa. Untuk dapat mengoptimalkan model pembelajaran tersebut dan meningkatkan penguasaan konsep dan kreativitas siswa, peneliti menggunakan virtual lab sebagai media eksperimen peserta didik. Peserta didik akan lebih termotivasi dan interaktif karena penyajian praktikum yang dilakukan dapat menarik minat peserta didik dan lebih efektif.

Berdasarkan latar belakang masalah tersebut, dapat diidentifikasi masalah dalam kegiatan belajar mengajar fisika adalah kurangnya kreatiivtas siswa dan rendahnya kemampuan siswa untuk bertanya dan menjawab pertanyaan. Rumusan masalah dalam penelitian ini adalah: bagaimana pengaruh model pembelajaran langsung berbantuan media laboratorium virtual terhadap kreativitas fisika siswa SMA?

\section{TINJAUAN PUSTAKA}

\section{A. Model Pembelajaran Langsung}

Menurut Setyosari [4], model pembelajaran langsung adalah model pembelajaran yang dirancang khusus untuk menunjang proses belajar siswa yang berkaitan dengan pengetahuan deklaratif dan pengetahuan prosedural yang terstruktur dengan baik yang dapat diajarkan dengan pola kegiatan yang bertahap selangkah demi selangkah. Istilah lain model pembelajaran langsung antara lain training model, active teaching model, mastery teaching, explicit instruction [3].

\section{B. Media Laboratorium Virtual}

Laboratorium virtual adalah laboratorium maya berbasis komputer interaktif yang mengintergrasikan berbagai komponen media dalam bentuk teks, gambar, animasi, suara dan video. Dalam mengembangkan laboratorium virtual terdapat beberapa rangkaian kegiatan mulai dari penyusunan Garis Besar Program Media (GMPM). Analisis instruksional (AI), flowchat, penulisan naskah, dan pemprograman dengan Macromedia Flash. Produk akhir laboratorium virtual dikemas dalam bentuk Compact Disc (CD) [6].

Laboratorium virtual biasanya didefinisikan sebagai: (1) tempat yang dilengkapi untuk eksperimen studi dalam ilmu pengetahuan atau untuk pengujian dan analisa, tempat memberikan kesempatan untuk bereksperimen, pengamatan, atau praktek dalam bidang studi, atau (2) periode akademis disisihkan untuk laboratorium bekerja [7].

\section{Kreativitas}

Ketika membahas tentang kreativitas, kita sering berpikir mengenai suatu penemuan ilmiah besar ataupun sebuah karya seni terkenal. Tetapi kreativitas tidak hanya membahas mengenai ilmiah atau kesenian. Kita membutuhkan kreativitas untuk menyelesaikan berbagai macam masalah yang kita hadapi dalam kehidupan. "Creativity is a matter of coming up with new ideas that are also useful" [8]. Hal ini berarti bahwa kreativitas adalah hal yang muncul dari ide-ide baru dimana akan disebut kreatif jika hal tersebut selain baru juga berguna.

Menurut Munandar [9], kreativitas adalah kemampuan untuk membuat kombinasi baru, berdasarkan data, informasi atau unsur-unsur yang ada. Hasil yang diciptakan tidak selalu hal-hal yang baru, tetapi juga dapat berupa gabungan (kombinasi) dari hal-hal yang sudah ada sebelumnya. Guilford dalam [9] menyatakan kreativitas merupakan kemampuan berpikir divergen atau pemikiran menjajaki bermacam-macam alternatif jawaban terhadap suatu persoalan, yang saman benarnya.

Berdasarkan berbagai pendapat di atas, dapat disimpulkan bahwa kreativitas merupakan kemampuan seseorang untuk menghasilkan suatu produk yang baru ataupun kombinasi dari hal-hal yang sudah ada sebelumnya, yang berguna, serta dapat dimengerti.

\section{Metode penelitian}

Penelitian ini adalah penelitian eksperimen. Menurut Sugiyono [10], penelitian eksperimen adalah penelitian yang melakukan perubahan (perlakuan khusus) terhadap variabel-variabel yang diteliti. Penelitian eksperimen meneliti ada tidaknya 
hubungan sebab akibat serta seberapa besar hubungan sebab akibat tersebut dengan cara memberikan perlakuan-perlakuan tertentu pada beberapa kelompok eksperimental dan menyediakan kontrol untuk perbandingan. Desain penelitian yang digunakan adalah Pretest-Posttest Control Group Design. Pretest-Posttest Control Group Design yang secara umum bentuk designnya seperti pada tabel 1 berikut:

\begin{tabular}{ccccc}
\multicolumn{5}{c}{ Tabel 1. Desain Penelitian } \\
\hline $\mathrm{P}$ & $\mathrm{O}_{1}$ & $\mathrm{X}$ & $\mathrm{O}_{2}$ & $\begin{array}{c}\text { (kelompok } \\
\text { eskerimen) } \\
\text { (kelompok } \\
\text { kontrol) }\end{array}$ \\
$\mathrm{P}$ & $\mathrm{O}_{3}$ & & $\mathrm{O}_{4}$ & \\
\hline
\end{tabular}

(Diadaptasi dari Setyosari, 2012)

Kedua kelompok dipilih berdasarkan pertimbangan atau tujuan tertentu, yang ditandai dengan $\mathrm{P}$. pada alanya keduanya diberi pretes $\left(\mathrm{O}_{1}\right.$ dan $\mathrm{O}_{3}$ ). Bedanya kelompok yang satunya diberi perlakukan (X), sedangkan kelompok yang lain tidak dikenai perlakuan melainkan dijadikan sebagai kelompok kontrol. Sebernanya kedua kelompok tersebut sama-sama emndapatkan perlaukan, tetapi keduanya mendapatkan perlakuan yang berbeda. Setelah perlakuan pada kedua kelompok selesai, kedua kelompok sama-sama diberikan post-test $\left(\mathrm{O}_{2}\right.$ dan $\mathrm{O}_{4}$ ).

Populasi dalam penelitian ini adalah seluruh siswa kelas $\mathrm{X}$ SMAN 1 Selong tahun ajaran 2015/2016 yang berjumlah 10 kelas. Teknik Sampling yang diguanakn adalah purposive sampling yaitu dengan tujuan tertentu. Instrument yang digunakan untuk mengukur kreativitas ada dua jenis yaitu TKV (Tes Kreativitas Verbal) sebanyak 6 soal uraina dan TKF (Tes Kreativitas Figural) sebanyak 3 soal uraian. Indikator yang digunakan dalam tes kreativitas ini adalah (a) Kelancaran (fluency) (b) Keluwesan (flexibility) (c) Keaslian (originality) (d) Terperinci (elaboration) (Munandar, 2012).

Sebelum instrument kreativitas TKV dan TKF digunakan, instrument divaliditas oleh para ahli. Analisis data yang digunakan dalam penelitian ini adalah uji homogenitas menggunkan uji-F, pada taraf signifikan 5\% jika $F_{\text {hitung }} \leq F_{\text {tabel }}$, data homogen dan jika $F_{\text {hitung }}>F_{\text {tabel, }}$, data tidak homogen, uji normalitas menggunakan persamaan Chi-kuadrat, data terdistribusi normal jika $\chi_{\text {hitung }}^{2}<\chi_{\text {tabel }}^{2}$ taraf signifikansi $5 \%$ dengan derajat kebebasan, $\mathrm{dk}=\mathrm{k}-1$, dimana $\mathrm{k}$ menyatakan jumlah kelas interval. Untuk mengetahui peningkatan nilai sebelum dan sesudah perlakuan digunakan uji-t Polled Varian.

\section{HASIL DAN PEMBAHASAN}

Penelitian ini bertujuan untuk megetahui apakah terdapat pengaruh model pembelajaran langsung berbantuan media laboratorium virtual terhadap kreativitas fisika siswa kelas X SMAN 1 Selong. Instrument yang digunakan untuk mengukur kreativitas siswa hanya menggunakan validitas ahli materi. Setelah validitas ahli, instrument dapat diberikan kepada siswa kelas eksperimen dan kelas kontrol. Instrumen kreativitas tersebut digunakan untuk mengukur kemampuan verbal dan figural siswa. Instrumen kreativitas verbal dan kreativitas figural ini digunakan untuk mengetahui data kemampuan siswa sebelum dan sesudah perlakuan. Sebelum perlakuan diberikan tes kemampuan awal (Pre-test) dan tes akhir (Post-test). Tes kreativitas yang digunakan berupa uraian yaitu 6 soal kreativitas verbal dan 3 soal kreativitas figural.

Kemampuan siswa kelas eksperimen dan kelas kontrol terlihat terdapat perbedaan yaitu adanya peningkatan kreativitas fisika siswa pada kelas eksperimen maupun kontrol yang ditandai dengan adanya kenaikan nilai rata-rata siswa.

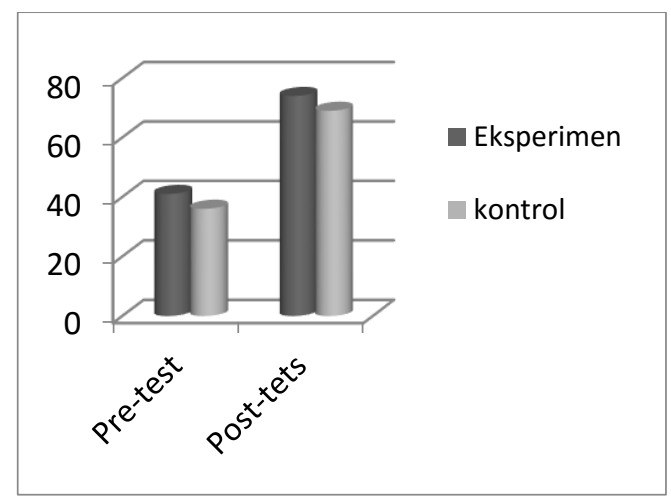

Gambar 1. Histogram Kreativitas Fisika kelas Eksperimen dan Kelas Kontrol

Dari gambar 1 terlihat bahwa terdapat peningkatan dari skor rata-rata pre-test dan post-test. Namun setelah menghitung secara matematis peningkatan nilai rata-rata kedua kelas sesudah diberi perlakuan untuk kelas eksperimen sebesar 33 (dari 41 menjadi 74) sedangkan pada kelas kontrol sebesar 33 (dari 36 menjadi 69), tidak terdapat perbedaan.

\section{Kreativitas Verbal}

Tes kreativitas verbal merupakan tes yang mengaju pada kemampuan akan penguasaan kata, bahasa serta penentuan jelas atau tidaknya mengenai ide-ide yang disampaikan. Hasil tes kreativitas verbal yang diperoleh pada kelas eksperimen dan kontrol, dimana nilai per item dijelaskan dalam tabel 6 berikut: 
Tabel 6. Nilai Pre-tes dan Post-test Kreativitas Verbal

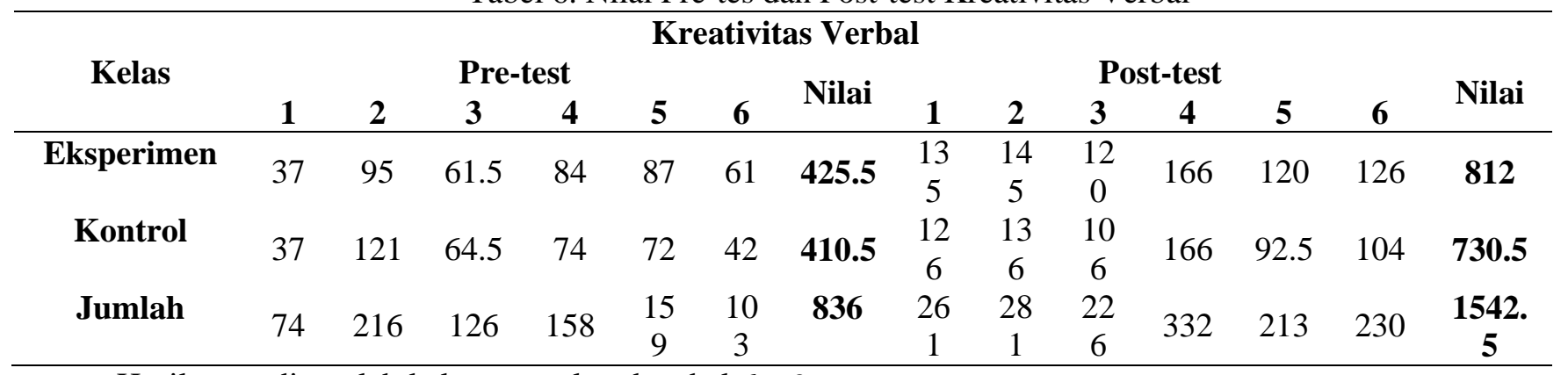

Hasil yang diperolah kelas sampel pada tabel 6 dapat disimpulkan bahwa selisih peningkatan kelas eksperimen lebih tinggi dibandingkan kontrol dari Pre-test ke Post-test yaitu 386,5, sedangkan kelas kontrol sebesar 310. Kreativitas verbal pada kedua kelas untuk setiap soal mengalami peningkatan secara signifikan. Hal ini menunjukkan bahwa model pembelajaran langsung berbantuan media laboratorium virtual cocok untuk meningkat berikut: kemampuan verbal.

\section{Kreativitas Figural}

Kreativitas figural diukur menggunakan tes kreativitas figural yang terdiri dari komponen kreativitas seperti menyusun kemungkinan rangkaian dari gambar, melengkapi gambar hingga menggambar proses suatu kejadian secara lengkap. Hasil tes kreativitas figural yang diperoleh pada kelas eksperimen dan kontrol dapat dilihat pada tabel 7

Tabel 7. Nilai Pre-tes dan Post-test Kreativitas Figural

\begin{tabular}{|c|c|c|c|c|c|c|c|c|}
\hline \multirow{3}{*}{ Kelas } & \multicolumn{8}{|c|}{ Kreativitas Figural } \\
\hline & \multicolumn{3}{|c|}{ Pre-test } & \multirow{2}{*}{ Nilai } & \multicolumn{3}{|c|}{ Post-test } & \multirow{2}{*}{ Nila } \\
\hline & 1 & 2 & 3 & & 1 & 2 & 3 & \\
\hline Eksperimen & 117 & 110 & 19.5 & 246.5 & 156 & 152 & 90 & 398 \\
\hline Kontrol & 97 & 91 & 16 & 204 & 127 & 162 & 94.5 & 383.5 \\
\hline Jumlah & 214 & 201 & 35.5 & 450.5 & 283 & 314 & 184.5 & 781.5 \\
\hline
\end{tabular}

Berdasarkan tabel 7 dapat dilihat peningkatan per item soal dari pre-test hingga post-test. Namun jika dilihat secara keseluruhan perbandingan peningkatan kelas eksperimen 151,5 sedangkan kelas kontrol 179,5 , peningkatan pada kelas kontrol lebih besar dibandingkan kelas eksperimen. Hal tersebut disebabkan karena kemampuan figural pada materi elastisitas kurang efektif diajarkan menggunakan model pembelajaran langsung berbantuan media laboratorium virtual.

\section{PENUTUP}

Berdasarkan uji hipotesis, dapat disimpulkan bahwa terdapat perbedaan kreativitas fisika siswa antara kelas eksperimen yang diberikan perlakuan berupa penerapan model pembelajaran langsung berbantuan media laboratorium virtual dengan kelas kontrol yang diberikan perlakuan berupa penerapan model pembelajaran konvensional tanpa bantuan media laboratorium virtual. Karena secara keseluruhan kreativitas fisika kelas eksperimen lebih tinggi dari kelas kontrol maka dapat dikatakan bahwa penerapan model pembelajaran langsung berbantuan media laboratorium virtual berpengaruh positif terhadap kreativitas fisika kelas X SMAN 1 Selong.

\section{UCAPAN TERIMA KASIH}

Terima kasih disampaikan kepada Tim Hibah Penelitian Strategis Nasional Kemenristek Dikti Tahun 2016 yang telah melibatkan kami dalam penelitiannya, membimbing dan mengajarkan banyak hal, serta memfasilitasi semua proses hingga publikasi ilmiah bersama.

\section{REFERENSI}

[1] Dahar, Ratna Wilis. 1996. Teori-Teori Belajar. Bandung: Erlangga.

[2] Gunawan. 2015. Model Pembelajaran Sains Berbasis ICT. Mataram: FKIP Universitas Mataram.

[3] Shoimin, A. 2014. 68 Model Pembelajaran Inovatif dalam Kurikulum 2013. Yogyakarta: ArRuzz Media.

[4] Setyosari, P. 2012. Metode Penelitian Pendidikan dan Pengembangan. Jakarta: Kencana Prenada Media Grup.

[5] Arnika, D., Kusrini, 2014. Penerapan Model Pembelajaran Langsung (Direct Instruction) Dengan 
Metode Kumon Pada Materi Persamaan Lingkaran Di Sman-1 Krian. Vol 1, No 3. MathEdunesa.

[6] Trianto. 2013. Mendesain Model Pembelajaran Inovatif, Progresif dan Kontekstual. Jakarta: Prenadamedia.

[7] Jaya, H. 2012. Pengembangan Laboratorium Virtual untuk Kegiatan Praktikum dan Memfasilitasi Pendidikan Karakter di SMK. Jurnal Pendidikan Vokasi. 2(1): 84-85.

[8] Loe, Joe Y. F. 2011. An Introduction to Creativity. United States of America: John Wiley \& Sons, Inc.
[9] Munandar, U. 2012. Pengembangan Kreativitas Anak Berbakat. Jakarta: Rineka Cipta.

[10] Sugiyono. 2012. Statistika untuk Penelitian. Bandung: Alfabeta.

\section{Biografi Penulis}

Ria Rizki Ekasari, lahir di Selong 8 Desember 1993. Tahun 2012 lulus di SMAN 1 Selong dan melanjutkan pendidikan S-1 di Universitas Mataram pada program studi pendidikan fisika hingga meraih gelar sarjana pendidikan pada tahun 2016. 